\title{
Penal Mediation in the Framework of Juvenile Deliquency in Albania. Education or Re-education
}

\author{
PhD Besnik Çerekja
}

besnik.cerekja@gmail.com

\section{Doi:10.5901/ajis.2014.v3n4p269}

\begin{abstract}
In this study I will attempt to provide the readers a clear overview of Albanian legislation in the field of penal mediation, further referring to mediation in the framework of juvenile delinquency which is its specific scope. Criminal acts cause serious consequences to both the victims and offenders. Accordingly, there is a need to further explore their deviant behavior for the purpose of rectification and rehabilitation. Thus, mediation becomes an incentive for rehabilitation of the victim and of the accused. A criminal imprisonment sentence against the accused often causes their depersonalization and creates an insurmountable distance between the convict and the social community he/she belongs to. Mediation in criminal matters as provided for in the Albanian legislation in force encompasses the possibility of litigants to resolve conflicts between them through accountable cooperation in order to find an amicable settlement. The mediator gives room to conduct negotiations in criminal matters. Though, the scope of application of penal mediation, not only in Albania but beyond, is unfortunately limited to a restricted number of provisions, mainly referring to criminal contraventions.
\end{abstract}

Keywords: Mediation, reconciliation, restorative justice, juvenile, criminal process, mediator, probation, diversion, victim, injured party, criminology, responsible, education, re-education, conflict.

\section{Part 1}

\section{Importance of Mediation}

Mediation is a crucial legal institution of a country as it plays a vital role in the rule of law system. Resolution of conflicts by mediation and procedures for its accomplishment reduce working costs of the judicial administration in particular and of the justice system in general. The judicial economy it carries per se cause substantial incomes saved in a long term perspective to be potentially used in other daily life areas. One of them would be the education/awareness of generations about the mediation process values and enhanced sensitization of social community to such a key institute. Mediation serves as absorber of a series of social issues, resolving criminal and civil disputes within a very short period and effectively, thus promoting the fast rehabilitation of the perpetrator, especially the rapid psychological recovery of the victim, regulating their conflicts on the basis of an agreement.

I wish to place the focus precisely on the victim's rehabilitation as the justice system has never taken it into account although in the first place, more than anybody else, it is the victim or the injured party who directly suffers the offence consequences.

Secondly, the social community is affected by the criminal offence. Sufferings of the individual as a member of a particular social community, from a broader and a more distant perspective, are translated into "sufferings" for the social community where the offence was committed. Therefore, I deem the consideration of the "victim's sufferings" and "their rehabilitation" as crucial since they are the ones reducing the life quality level within a specific social community, increasing the level of anxiety of individuals and life insecurity of the latter and within the community they belong to.

Thirdly, the state is prejudiced, which by its punishment reaction to the perpetrator, seeks to restore social peace through the application of criminal sanction, imprisonment sentence or fine, converted to financial value, which goes in favor of the state's budget, without taking into account damages caused to the victim or the injured party. Indeed, the criminal procedural legislation, through the institute of "civil lawsuit in criminal process", affords an opportunity to the injured party (Article 61 of the Albanian Criminal Procedure Code) to claim compensation of the damage caused from the criminal offence. Yet, this method does not ensure rehabilitation of the victim in psychological and social field. Instead, it strongly escalates the conflict between the parties which will be further aggravated in the course of implementation of the criminal process where the injured party is interested. They will make their utmost so that the defendant is found guilty 
and be sentenced for the commission of criminal acts he/she has allegedly committed considering it as the only way to prove the defendant's liability, being a prerequisite to benefit damage compensation. This trend of the "civil defendant" which naturally goes toward the punishment of offence perpetrator is in full contravention to the principles and purpose of restorative justice, which aims to exclude the perpetrator from the criminal justice system characterized by the punishment/sanctioning component, applying thereto the restorative justice.

However, under the best scenario, the injured party would have the possibility of financial compensation but for sure the conflict, dispute and personal relations with the crime perpetrator or from a broader perspective with the respective families, would be seriously aggravated, thus intensifying the feeling of fear and social insecurity and at the same time reducing life quality within the community.

According to data collected in the course of studies conducted, the resolution of conflicts and reconciliation of disputes in Albania has not merely remained on theoretical level but has started to be practically implemented. This initial positive step generally shows that the concept is driven to the mediation mission for reconciliation as a noble mission and moral obligation assumed to be met by each mediator. The statutory institutionalization of the mediation process in Albania, after 1999, demonstrates the objectives and goals of not only the civil society but also of lawmaking political groups to particularly highlight mediation among the dispute settlement options.

Clearly, the practical implementation of mediation for the resolution of conflicts and reconciliation of disputes is linked with a series of objective and subjective factors of various difficulties and obstacles but not overwhelming ones. The fact that reconciliation mediations are carried out in almost all country districts means that a larger number of outcomes may be produced due to a higher level of commitment and professional skills. Further, a positive fact is that efforts are made for the resolution of various conflicts and disputes from family and property related ones up to the reconciliation of blood feuds.

The organization of the Central Commission for Reconciliation of Bloodfeuds, as well as the establishment of "bloodfeud reconciliation" commissions and of the Foundation for Resolution of Conflicts and Reconciliation of Disputes (in 1995) proved to be major steps for the institutionalization of organizational measures against bloodfeud and revenge. The cooperation and interaction of heads of villages with those organizations, public order bodies, organizations and associations and justice authorities, were main measures for the reconciliation of bloodfeuds, as it was further established in the districts of Kurbin, Krujë, Mirditë, Tropojë, Shkodër etc. A key role for the reconciliation of bloodfeuds was also played in the past by religious institutions, such as churches and mosques, which preach forgiveness and reconciliation as a God commandment. This is also testified by the activity of the group of Reconciliation Missionaries, which over the period 1991-1994, managed to reconcile many families involved in hostilities. Ndrekë Pjetri and the Franciscan monk Dionis Maka were well-known during that period for reconciliation of 158 bloodfeuds in all zones, 70 per cent of which in the North. They have prevented murders due to bloodfeud, enabling reconciliations between Albanian people abroad as in Greece, Turkey etc. (Prof. Dr. Ismet ELEZI in "Mediation for reconciliation of criminal disputes", Tirana, 2004).

In this context, we cannot place the focus on mediation activity of the Foundation for Resolution of Conflicts and Reconciliation of Disputes, which has been operating in the field of mediation for 18 years, providing major contribution to the resolution of various civil and penal conflicts, especially referring to the mediation for reconciliation of bloodfeuds in mountainous areas where the phenomenon of bloodfeud is widespread.

To focus on the very core of this study, referring to conflicts attributing the juvenile as a perpetrator, we emphasize that by term "juvenile" the current Albanian legislation means the whole age group of citizens under 18 years of age, who act in contravention to the criminal law due to commission of a criminal offence. As already known, it is mostly about criminal contraventions. Considering the low risk of those criminal acts, implementation of restorative justice programs to this class of perpetrators is deemed necessary, making possible their immediate exclusion from the criminal system ${ }^{1}$, far from the impact of measures of punitive/coercive character, which, if on one hand render "the deserved" punishment against the person violating common living rules, on the other hand enable that perpetrators of the so called "petty" offences characterized by their low social risk, receive adequate information within the premises of penitentiary institution "to be further rehabilitated and specialized" in committing offences of even higher social risk. This component becomes more dangerous if it is about juvenile perpetrators. Apart from any other interests that may be considered valuable and instrumental, I believe that the highest interest in this case, at a time when prevention is almost impossible, is the

\footnotetext{
${ }^{1}$ This is also provided for in letter b), third paragraph of article 40 of the "Convention on Rights of Child", providing for that the Member States "Adopt measures, whenever it is deemed necessary and desirable", to treat these children without referring to the judicial procedure, provided that human rights and legal protection are fully respected"
} 
promotion of re-integration of the juvenile perpetrator in the society, involving the latter and his family in this process.

A table produced by the Foundation "Resolution of Conflicts and Reconciliation of Disputes" in the manual "Case Studies" referred to the Model of Mediation between the victim and offender, is highly significant, wherefrom the value and function of mediation is clearly set out in only three lines.

\begin{tabular}{|l|l|}
\hline Criminal justice & Restorative justice \\
\hline Which laws are violated? & Who is the injured party? \\
\hline Who violated them? & What are their needs? \\
\hline How should they be punished? & Who will address these needs? \\
\hline
\end{tabular}

Accordingly, as it may be easily observed, while the criminal justice aims to identify the infringed legal provisions, potential perpetrator or perpetrators and applicable sanctions, the restorative justice aims to identify the injured party, needs of parties involved in the conflict and natural persons and legal entities to address those needs.

In this context, I would like to place the focus on what the numerous authors and operators of the field, psychologists and lawyers who are already licensed and exercise at least in theory, the profession of mediator, fail to assess or classify this last need in the order of values posed by mediation, according to their perspective. In all interviews I have conducted for the purpose of this study, everyone placed the focus, often raising their voice worriedly, on the need of public funds supporting the work of mediator and none of them sought and neither mentioned the need for application of mediation programs which, since early stages of education, might by easily realized with the introduction in school curricula and syllables of core principles on which mediation is based.

As it will be noted below, current legislation in the field of mediation has foreseen and clearly regulated the representation of mediators, method of their organization, mediation process etc, thus building a professional image, a freelance profession equal to freelance professions such as the lawyer's service, notary service etc but in contrast to the latter, the mediators, often fairly highlight the difference with those professions. While clear fees also approved by bylaws are provided for those professions, in respect of mediation, referring in particular to the mediation in criminal matters, mediators are confronted with perpetrators and victims/injured parties, who are under a devastated economic situation, grounds for which they would never be able to pay the mediator for the implemented service. Therefore, in manifest absence of mediation-oriented culture, in addition to the difficulties to lead parties to an extrajudicial conflict resolution, the mediators have to exercise a profession to not derive financial incomes as their "clients" have no incomes and would not pay the mediator even if they wished to. This is the point generating their choice to participate in mediations of civil character, wherefrom there naturally arises the issue of non-commitment of licensed mediators in mediation activities in criminal matters. Hence, this activity is mostly carried out by the present local NGO-s operating on the basis of donations and projects.

The question that naturally arises is: what will happen with mediation in criminal matters and perpetrator, victim and other related stakeholders, if those NGO-s are not any longer able to derive incomes from various donors regarding the projects providing for mediation in juvenile delinquency? What will happen in that case with juvenile perpetrators, either be criminal contraventions?

During more than 20 years of transition, while an extensive and admirable work is done in the field of mediation in general and in criminal mediation in particular, as regards the preparation of an advanced and modern legislation, we cannot admit the same about the enhancement of mediation culture within the community and beyond. As highlighted by a large number of researchers but as it is easily understood by anyone who reads an article or manual about mediation, mediation is above all a "mentality". First of all, mediation is a school of thought, a way of understanding and finally a way of acting. To put it differently, in order to work, mediation should be part of the person's outlook, either be a perpetrator, victim or field professional. The existence of this outlook or mentality is a sine qua non condition. We cannot refer to the possibility of application of mediation or its broader distribution.

While this basic need is growingly applied in civil and commercial matters as the business community, more than anywhere else, feels the effects and advantages it brings, referring to the duration and costs they face if they will refer to the judicial procedures, mediation in criminal matters finds it hard to penetrate the people's mentality. This challenge is an outcome of a series of factors among which we may mention the non-functioning of police system and judicial system, including the prosecutor's office, low educational and economic level of individuals, corruption in public administration and the poor cultural performance of social community.

The police system does not operate as police officers and agents who work on site who are the first ones to be exposed to the offence and its perpetrator, are not able to guide the parties to mediation process but are prone to punishment and hurry to refer the case to the prosecutor's office, in accordance with the criminal and procedural criminal 
legislation in force.

Apparently, their eagerness is oriented to the report of cases in question, further interpreting them in official statistics as an effective work done "to increase crime detection". These statistics will be further published in websites of the respective district prosecutor's offices and courts which will "take pride" with their decisions of punitive character, where two elements will be easily highlighted: small scale risk of the offence committed and young age of perpetrator/s. These are typical cases which might be referred to and successfully resolved by mediators.

The non-functioning of judicial system is above all linked with the preparation and sensitization of judges to consent to mediation and refer cases brought to the mediator and secondly it is linked with the above statistical grounds as they will hurry to render a sentence against the perpetrator/s since in this way it would clearly follow that the fight against criminality is effective. Unfortunately, the requirements for evaluation of judges' work by inspectors of the Ministry of Justice or the High Council of Justice is precisely based on these standards, where the high level punishment of the tried and sentenced perpetrators and of respective judgments is a benchmark for positive evaluation of the judge's work.

The low educational and economic level drastically increases criminality. To put it simply, the absence of education naturally makes the person become "contingent" to crime and criminal gangs as the latter are oriented to this category of persons to increase the number of their members. On the other hand, absence of financial incomes makes this class of persons or social groups be naturally oriented to the commission of criminal offences, often with the sole purpose of survival for feeding purposes. This may be evidenced by putting forward many concrete cases but the most significant evidence shown during the interview with Mr. Rasim GJOKA2, is the one where a juvenile was "caught in the act" by the police officer as after the call of the owner of a pie shop, it followed that the perpetrator had stolen two pieces of pie at a price of $20 \mathrm{ALL}$ each.

To further proceed, the juvenile "caught in the act" by the police officer was criminally prosecuted by the prosecutor's office and finally he was sentenced by the Court by a judicial decision as according to the latter, theft resulted proven notwithstanding the small scale risk of the perpetrator and low value of the affected property.

Literally, this is the most significant case of crimes committed on grounds of survival for feeding purposes and the most typical case of criminal offences, where more than ever all justice system operators should be oriented to the exclusion of subject-perpetrator from the judicial system, guiding him/her to the mediation process.

Corruption in public administration is another factor thwarting the increase of cases referred to the mediator as the actions of crime perpetrator are largely deemed as a possibility to financially "benefit" from it. Once an offence is committed, the author immediately contacts justice operators such as police agents, prosecutors, psychologists, judges, without excluding the probation service experts. All this "army" of public administration officials and professionals deem the process to be undergone or not by the perpetrator, either be a juvenile, as a potential illegal profit, often exerting pressure on the perpetrator or his/her relatives.

Last but not least, the low cultural level of community, being unaware and insensitive to those practices, make them be almost "invisible" in terms of conflict management affecting them and the members of that community, from the moment when the conflict-dispute has arisen therefrom. As we previously had the occasion to share information, the increase of criminality within a particular social community significantly increases insecurity, thus reducing the life quality of gang members.

Following this observation we are urged to strongly re-raise the argument that in the context of the management of conflicts or various disputes arising among a specific social community, its members should actively participate in their resolution as those members are the ones to be better aware of the problems of its members. These members are the ones to suffer "at their expense" the consequences of conflicts within the community, thus being directly interested not only in the resolution of concrete case presented but also in terms of mitigation or uprooting of negative aftermaths of the criminal offence in subsequent inter-personal relations of its members.

Nevertheless, how may we reach this stage?

To borrow a term from English language but often used by almost all operators interviewed during the preparation of this study which I deem highly relevant, I would admit there is a need for open minded people. The closest connotation means transparent persons. We need Albanian educated, well-mannered citizens under good economic conditions, with a high level of mediation culture, self-conscious and with a high level of civil awareness.

How can it be achieved? 2 Mr. Rasim GJOKA is the present administrator and one of founders of the Foundation "Settlement of Conflicts and Reconciliation of
Disputes" 
It would be probably an utopia to claim to encounter these characteristics among all citizens, part of a specific social community. Yet, we should do our best they are possessed by all those citizens who are part of a justice system. If we cannot guarantee good economic conditions for all citizens, we should at least concentrate our efforts in their education, particularly for the introduction of civic education and the education of those generations under sound principles on which mediation is based, principles instructing coexistence within a social community.

These educational programs must be part of educational programs and curricula, starting with kindergartens, elementary schools and continuing at least until the completion of compulsory school education.

On the basis of the foregoing, without striving to instill negativism and deny the fact that extensive work has been done and is still carried out by various operators, natural persons or legal entities, exemplifying the work of the latter, we may surely admit that during 2012-2013 the Foundation "Resolution of Conflicts and Reconciliation of Disputes", in cooperation with the Probation Service Directorate General, is implementing the project "Enforcement of Restorative Justice and Mediation between Victims and Offenders in the Probation Service", supported by the EU Delegation in Tirana and UNICEF (http://www.mediationalb.org/mat.php?-a\&idm=141\&idr=55;).

Taking into account the values of mediation and advantages it brings for the mitigation and abolition of criminal disputes in the society, hard efforts have been made during these years in Albania in to legally regulate this institute. Therefore, for a period of 14 years mediation has been institutionalized and regulated by a special organic law. Amendments to the legislation have been radical as during all these years since 1999, three laws were adopted which repealed the previous law.

Accordingly, article 20 of Law No. 9090 dated 26. 6. 2003 "On mediation for settlement of disputes" has fully repealed the law No. 8465 dated 11. 3. 1999 "On mediation for settlement of disputes by reconciliation" and article 27 of Law No. 10385 dated 24. 2. 2011 "On mediation for settlement of disputes" repealed the previous law No. 9090 dated 26.6. 2003 "On mediation for settlement of disputes".

To better understand the development of legislation in this field, let us proceed with the analysis of those laws, starting with the law of 1999 up to the current situation of legislation in the field of mediation, Law No. 10385 and bylaws for its implementation.

\section{Mediation according to Law No. 8465 dated 11. 03. 1999 "On resolution of conflicts and reconciliation of disputes"}

The approval of Law No. 8465 dated 11. 3. 1999 "On mediation for resolution of disputes by reconciliation" (Law No. 8465 dated 11. 03. 1999, Official Journal No. 3/1999) is of major and multidimensional importance. Firstly, it is attached social importance and values as in view of reconciliation, mediation amicably resolves social conflicts, avoids arguments, separations, develops a sense of tolerance between people and social groups, thus promoting the emancipation and civilization of the Albanian society. Secondly, the law poses historical and topical importance (particularly with reference to the time-related context) as in resolving disputes by reconciliation, it restores the ancient tradition of the Albanian people on mediation for reconciliation under new historical conditions, harmonizing it with the positive modern experience of democratic states. Thirdly, the approval of law has a special legal importance as it frames the mediation for reconciliation on sound legal basis, institutionalizes it by also regulating the relations with the court, prosecutor's office, other state bodies and non-profit organizations. Fourthly, the law has not lesser importance from the practical aspect of the settlement of disputes by reconciliation as it contains key principles and detailed procedural rules and specifically defines fields and categories of criminal offences to which mediation for reconciliation shall apply. Therefore, in a democratic society there are all available options, so that mediation by reconciliation is strongly supported by grassroots and this alternative will have a safe future.

Though, we believe that attainment of this result requires a major comprehensive commitment of all stakeholders such as politics, civil society, subjects of criminal processes in particular and subjects operating in the field of justice in general, social community, non-profit organizations etc.

Based on the historical experience of our people and the one of contemporary democratic countries, the Foundation "On resolution of conflicts and reconciliation of disputes", has actively assisted with the preparation of the respective draft law. Excluding the mediation of family and property conflicts by reconciliation, as we will further note, this law also provided for the settlement of criminal disputes. The Criminal Procedure Code served as a legal basis in this regard, and in articles 59 and 284 it provided for that criminal offences handled by complaint of the injured party may be resolved via extrajudicial channels.

As it may be reported from the analysis of the law in question, mediation is conceived as an extrajudicial activity 
carried out by a third party (mediator) for the reconciliation settlement of disputes between citizens, between them and legal entities (private and/or state ones) or between the latter.

In the meaning of this law, the disputes for which judicial settlement is compulsory, cannot be resolved by mediation, implying that conflicts which may be subject to mediation are expressly provided by law. As an example to the foregoing, we may refer to the case of marriage dissolution for which the parties shall refer to the court as pursuant to law they may legally terminate marriage at that institution. In this case, parties "involved in the conflict" may refer to the court by a joint agreement in respect of marriage dissolution consequences but it is about the potential regulation of economic and social consequences by agreement between the parties while the court shall have the last say about the cease of marriage legal effects.

Mediation is intended to find an acceptable resolution by parties to the dispute, which is not contrary to law and best customs prevailing within a specific community.

In view of reflecting the historical background of legislation in the field of mediation, we will have an overview of the provisions of Law No. 8465 dated 11. 3. 1999 "On mediation for settlement of disputes by reconciliation".

Further, article 1 provides a definition of the term "mediation", describing it as an extrajudicial activity for the settlement of disputes by reconciliation. Article 2 of the law provides for that mediation is an independent social activity exercised in accordance with that law. Based on the constitutional principle of equality of arms before law (article 18), this law puts forward the principle that "mediation for settlement of disputes by reconciliation is based on equality of arms" for the respect of "individual values and impartiality" on case dissolution (article 3).

The deepest integrity permeated by the spirit of this law is the fact that during the process of reconciling mediation, both parties are winners in amicably resolving the dispute by respecting each other's individual values. Mediation impartiality is manifested during this process, thus boosting the authority and its belief and values. Article 6 of Law provides for that mediation is a bilateral educational process targeted to prevent judicial settlements of conflicts and mitigate their social consequences, harmonize the parties' interests thus leading to their mutual understanding.

Mediation aims to challenge the aftermaths derived within social groups as a consequence of criminal offences or other disputes. A factor to be taken into account and enshrined from this provision is that law attaches priority to the protection of interests and values of social community, to be protected against consequences derived as a result of criminal or civil disputes generated from the conflict.

Another key principle of mediation is its voluntary character. The parties to the conflict are free to choose mediation as an alternative of dispute at any time they deem appropriate, prior to the beginning of judicial process, during its implementation but also in the end, before the pronouncement of respective decision.

The confidential character of mediation, as provided for in the law in question, is a main component for the smooth process implementation since it enhances the trust of litigants in the mediation process in general and in the mediator in particular.

This component has been one of the items of Recommendation No. R (99) 19 of the Committee of Ministers addressed to member states in respect of mediation in criminal matters (Adopted by the Committee of Ministers on 15 September 1999 in the $697^{\text {th }}$ meeting of deputy ministers), providing for: "Deliberations during mediation shall be restricted information and cannot be subsequently used, save with the consent of parties" (Item 2 of the General Principles provided for in the Annex of RECOMMENDATIONS No. R (99) 19 of the Committee of Ministers addressed to member states in relation to mediation in criminal matters). This means that negotiations conducted by the parties during mediation and the respective documentation cannot be made public without their consent.

The law makes exceptions from this principle, envisaging that each party is entitled to use a document if it deems necessary. A core principle of mediation provided by law is that it results to be a bilateral educational process, aiming to prevent the judicial settlement of disputes and mitigate their social consequences, harmonize the interests of parties leading to their mutual understanding. Mediation aims to challenge the consequences deriving within social groups as a consequence of commission of criminal offences or other disputes.

The second paragraph of article 6 of Law clearly manifests a noble mission of mediation aiming to overcome the consequences arising as a consequence of criminal offences or other disputes. This is about the reconciliation of bloodfeuds, termination of hostilities between families involved in bloodfeud, breaking of families from self-isolation which represented and still represents one of the most important duties of the mediator (Elezi, I-"Mediation for reconciliation of criminal disputes", Tirana 2004). A basic principle included in the Law of 1999 is the one on which the process, as a rule, is conducted free of charge, unlike the judicial process burdening high judicial expenses, lawyer's fees etc..

However, it should be understood that under the main principle embodied in law, the latter makes exceptions, particularly in reference of expenses made for the purpose of dispute settlement (for instance, for the implementation of 
an expertise act) but not for the fee of mediator or mediators if the parties to conflict have chosen more than one. The main condition to be respected is the delivery of their preliminary written consent about the payment of the foregoing expenses. This principle is envisaged by article 7 of law: "If during mediation procedures, expenses attributable to parties are planned to be made, their preliminary written consent should be obtained about the price and payment modalities. The parties shall equally bear expenses, unless they otherwise agree".

As provided by article 8 of the Law, mediation activity is implemented by mediators elected only by non-profit organizations operating in this field, whose activity is supervised by the Ministry of Justice, the institution guaranteeing due implementation in the spirit of law on mediation activity.

Accordingly, at a time when mediator did not act in a professional capacity and therefore the Mediation Chamber as a body regulating the profession was absent, pursuant to law of 1999 , mediation takes place only through the involvement of non-profit organizations which are always committed free of charge to resolve conflicts arising within the society, when the society "seeks help" in this regard (articles 15 and 16 of Law).

Scope of application. Pursuant to the provisions of articles 10,11 and 12, the law has foreseen three main groups of disputes or conflicts that might be settled by reconciliation/mediation (Elezi, I-"Mediation for reconciliation of criminal disputes", Tirana 2004).

1. The first group of disputes that may be resolved by reconciliation are the ones of family character, property or non-property ones linked with the method of income management by spouses, non-payment of alimony to children or parents, division of marital assets after marriage dissolution and of heritage properties or assets.

2. Civil disputes between the private subjects arising from the violation of property rights and those arising from the cause of damages. Property-related conflicts are mostly involved, often causing devastating consequences. Conflicts over land borders and division of properties are the main scope of reconciling mediation activity. Disputes and conflicts emerge also in cases of non-execution of contracts or in the context of commercial disputes.

3. The third group involves criminal disputes that may be resolved by reconciliation. Regarding this group the law makes reference to articles 59 and 284 of the Criminal Procedure Code, specifying the criminal offences pursued upon the request of the accusing injured party or those subject to complaint for which mediation process may be initiated for the purpose of achieving reconciliation between the parties to the conflict. This group includes 17 criminal contraventions and 7 crimes such as beating, serious injury due to negligence, slight injury due to negligence, insult, libel etc. Pursuant to the provisions of this law, the settlement of criminal disputes by reconciling mediation is realized when consented with the free will of both parties, otherwise the case shall be resolved by the court. This resolution avoids other social and legal consequences such as revenge and bloodfeud as an expression of self-trial, separations or disruptions and hostilities between the parties and their relatives.

\subsection{Mediator and mediation process}

Moral figure and status of mediator. The doctrine pursues a dual approach if the mediator should be or not among legal experts or lawyers. There are controversial opinions about this matter (Cris M. Carrie. Should a mediator be among legal experts or lawyers "Reconciliation", Issue 1/2001). It is traditionally acknowledged that to be a mediator, in the past, some ethical-moral conditions and requirements had to be imposed, so that he/she would be generally known as a honest individual and enjoy the trust of parties as an impartial person with a good knowledge of local customs. A relative of the parties or their friend, a priest or imam, a man or woman might act as a mediator but in each case with the parties' consent (Elezi, I-"Mediation for reconciliation of criminal disputes", Tirana 2004).

Further, the Law No. 8465 dated 11. 3. 1999 is based on that tradition, taking into account that mediator should meet not only ethical-moral requirements but also some other legal criteria. According to article 15 of the law, a mediator may be: "...everyone who has turned 25 years old...", i.e someone with life maturity and experience, as a rule a Bachelor graduate with educational-cultural background, professional skills for resolving the issue. Further, a potential mediator should not bear previous criminal records and has to be distinguished for honesty, wisdom, smartness, enjoying the trust of people and experienced in social activities. These law requirements complete the figure of mediator. ${ }^{3}$

${ }^{3}$ As we will be able to refer by the end of this chapter, we believe that at least in cases of mediators in criminal disputes, the latter should be professionals exercising only the profession of mediator, thus excluding the exercise of mediation by active lawyers. Active lawyers 
The said requirements are necessary for the figure of mediator, in order to ensure his/her impartiality, unbiased approach and professionalism regarding the duty assigned to him/her on a case by case basis. This duty should be accomplished in full accordance with the criteria established by law.

As regards the mediation process, Law No. 8465 dated 11. 3. 1999, in addition to substantive provisions specifying the principles and fields of its activity, also contains procedural standards for the commencement and implementation of the mediation process. Article 13 of the Law of 1999 provides for that in cases when for matters provided under articles 10, 11 and 12 of this law, the court or prosecutor's office deems that the conflict may be resolved by mediation and parties do not object, it shall suspend the review of case and bring the case to the mediator for the purpose of review. If the conflict is not settled by mediation, this shall not prevent the court or prosecutor's office to resume legal proceeding upon the request of parties (Elezi, I- "Mediation for reconciliation of criminal disputes", Tirana 2004).

As noted, this is about civil family or criminal disputes. The reviewing proceeding has been already instituted at the court or prosecutor's office (for those cases falling within their powers) but when they deem the dispute may be resolved by mediation, they bring the case to the mediator. It is worth stressing the fact that such a procedure is followed with the consent of parties. Mediation, subject to the nature of dispute or request of the parties, is realized by one or several mediators. The mediator is voluntarily consented by the concerned parties. For the purpose of implementation and settlement of disputes, the mediator acts by:

a) Discussing beforehand with the parties about the nature and causes of dispute, in order to understand the nature and origin of conflict dividing the parties;

b) Posing the alternative options for the dispute settlement, in each case without imposing his/her opinions to the parties. This means that the mediator puts forward alternatives for the case settlement and urges the parties to resolve the conflict, in view of reaching an agreement accepted by all stakeholders involved.

c) Cooperating with the authorities of justice, public order, local government, Ombudsman and non-governmental organizations including within their main scope of activity the resolution of conflicts by reconciliation;

d) Requesting from the state competent bodies to adopt measures to prevent illegal causes and highlighting, as appropriate, their responsibilities (article 17). This is about those cases when illegal or irregular actions of public servants are attributable causes of conflicts or disputes.

The law excludes the possibility that mediator may be summoned as witness by the court or prosecutor's office about the facts he/she has been aware of in cases when he/she has mediated, save the cases when during the mediation process a criminal offence is committed and only in support of investigation of the latter. This guarantees the principle of confidentiality, a component enhancing public trust in the process and in the mediator. ${ }^{4}$

Article 20 et seq of the law provide for principles linked with the territorial competence of the mediator, time limits set for the termination of mediation process and cases of invalidity of mediation process or of the agreement reached by the end of that process. I will not detail those principles as I would thereby divert from the topic of the present study.

refer to lawyers who exercise the profession if supplied with the respective license issued by the National Chamber of Lawyers and the Tax Chamber (Taxpayer's Identification Number)

${ }^{4}$ In this meaning, see also the manual of Prof. Dr. Ismet Elezi "Mediation for reconciliation of criminal disputes", Tirana 2004, pp. 125126 


\section{References}

Recommendation No. R (99) 19 of the Committee of Ministers referred to member states regarding mediation in criminal matters (Approved by the Committee of Ministers on 15 September 1999 in the 697th meeting of deputy ministers).

Parlamenti i Republikës së Shqipërisë, (Law No. 7905 dated 21. 03. 1995), Criminal Procedure Code of the Republic of Albania, as amended.

Parlamenti i Republikës së Shqipërisë, (Law No. 7895 dated 27. 01. 1995), Criminal Code of the Republic of Albania, as amended.

Parlamenti i Republikës së Shqipërisë, (Law No. 8465 dated 11. 03.1999) "On resolution of conflicts and reconciliation of disputes".

Parlamenti i Republikës së Shqipërisë, (Law No. 9090 dated 26/06/2003) "On mediation for settlement of disputes".

Parlamenti i Republikës së Shqipërisë, (Law No. 10385 dated 24/02/2011) "On mediation for settlement of disputes".

General Assembly of United Nations Organization (20 November 1989) "Convention on rights of child".

Elezi I, (2004) "Reconciling mediation in criminal disputes", Tirana.

Cris M. Carrie, (2001), "Should the mediator be among legal experts or lawyers", Reconciliation.

Commentary of Law No. 10385 dated 24/02/2011 "On mediation for settlement of disputes"- Publication of the year 2012 prepared by a group of field experts, with the coordination of the Foundation "Resolution of Conflicts and Reconciliation of Disputes" and the School of Magistrates, under the auspices of UNICEF and IFC.

Dushku Q, (2007) "Adolescents in the long road of conflicts"- sociological, legal and cultural magazine "Mediation", Tirana.X 
